FEDERAL RESERVE BANK OF SAN FRANCISCO

WORKING PAPER SERIES

\title{
Safe and Sound Banking, 20 Years Later: What Was Proposed and What Has Been Adopted
}

\author{
Fred Furlong \\ Federal Reserve Bank of San Francisco \\ Simon Kwan \\ Federal Reserve Bank of San Francisco
}

August 2006

Working Paper 2006-27

http://www.frbsf.org/publications/economics/papers/2006/wp06-27bk.pdf

The views in this paper are solely the responsibility of the authors and should not be interpreted as reflecting the views of the Federal Reserve Bank of San Francisco or the Board of Governors of the Federal Reserve System. 


\title{
Safe and Sound Banking, 20 Years Later: What was proposed and what has been adopted
}

\author{
Abstract \\ In 1986, a task force of banking academics organized and sponsored by the \\ American Bankers Association convened to examine the banking industry and the \\ efficacy of its regulatory system. The group was charged with reviewing the problems of \\ ensuring the safety and soundness of the banking system and evaluating a number of \\ policy options to improve the efficiency, performance, and safety of the system by \\ changing the structure of the deposit insurance system and the bank regulatory and \\ supervisory process. The results of the work of the task force were published by the MIT \\ Press as the book, Perspectives on Safe and Sound Banking (Benston et al., 1986, the \\ Report), which includes a set of principal options and recommendations. The purpose of \\ this article is to assess the extent to which changes in public policy regarding depository \\ institutions have been aligned with the recommendations of the Report. We find that, \\ over the past 20 years, several legislative initiatives and changes in regulations and the \\ bank supervisory process have been in keeping with the specific recommendations of the \\ Report or with the analytic framework underlying the recommendations. At the same \\ time, other recommendations in the Report have not been taken up and some proposals \\ rejected in the Report have been put in place by legislative and regulatory initiatives. \\ Overall, public policy and private sector initiatives appear to have contributed to safer \\ and sounder banking and thrift sectors over the past 20 years. Consistent with what we \\ see as the main theme of the Report, a likely contributing factor is the more appropriate \\ alignment of incentive for risk-taking among larger depository institutions. \\ Developments affecting risk-taking by depository institutions likely include higher \\ capitalizations, greater risk exposure of private sector stakeholders more generally, \\ improvements in risk management, and supervision and regulation that is focused on \\ overall risk.
}


Safe and Sound Banking, 20 Years Later:

What was proposed and what has been adopted

\author{
Prepared for the \\ Conference on Safe and Sound Baking: \\ Past, Present, and Future
}

Sponsored by:

The Federal Reserve Banks of Atlanta and San Francisco

and the founding editors of The Journal of Financial Services Research

\author{
Frederick T. Furlong \\ and \\ Simon H. Kwan \\ Federal Reserve Bank of San Francisco
}

August 17, 2006

\title{
Introduction
}

In 1986, a task force of banking academics organized and sponsored by the American Bankers Association convened to examine the banking industry and the efficacy of its regulatory system. The group was charged with reviewing the problems of ensuring the safety and soundness of the banking system and evaluating a number of policy options to improve the efficiency, performance, and safety of the system by changing the structure of the deposit insurance system and the bank regulatory and supervisory process. The results of the work of the task force were published by the MIT Press as the book, Perspectives on Safe and Sound Banking (Benston et al., 1986, the Report), which includes a set of principal options and recommendations.

The recommendations in the Report focus on prudential supervision and regulation of depository institutions-commercial banks and thrift institutions. In putting forth the set of recommendations, the authors of the Report note that they explicitly were not addressing the political feasibility of adoption or existing legal limitations.

The underlying premise of the Report is that, in 1986, the extant administration of the federal safety net—deposit insurance and the lender of last resort—provided incentives for risk-taking by insured depository institutions. To address this issue, the Report puts forth recommendations intended to help ensure that the deposit insurance 
system is compensated for its risk exposure, reduce the overall risk exposure of the deposit insurance system, and align accountabilities for the administration of deposit insurance and lender of last resort with those for prudential supervision and regulation.

The timing of the Report and its emphasis on deposit insurance reform was propitious given the broader attention at the time being given to the moral hazard problems associated with mis-priced deposit insurance and the perception of de facto 100 percent insurance coverage of bank liabilities, at least for the largest banking organizations. Of particular concern in the mid-1980s was the precarious financial condition of many savings and loan associations, the so-called zombie thrifts. The eventual need to recapitalize the federal deposit insurance funds both for thrifts and banks attests to the need for reform of the deposit insurance system and changes in prudential supervision and regulation more generally.

The purpose of this article is to assess the extent to which changes in public policy regarding depository institutions have been aligned with the recommendations of the Report. We find that, over the past 20 years, several legislative initiatives and changes in regulations and the bank supervisory process have been in keeping with the specific recommendations of the Report or with the analytic framework underlying the recommendations. At the same time, other recommendations in the Report have not been taken up and some proposals rejected in the Report have been put in place by legislative and regulatory initiatives.

The recommendations that constitute the main body of the Report are those calling for risk-related pricing of deposit insurance, changes to the deposit insurance contract, changes to capital requirements, reliance on current (market) value measures of assets and liabilities, and other measures to enhance market discipline. The authors in general rejected the use of limiting activities of depository institutions or the use of limits on deposit interest rates. However, they did link the expansion of banking powers to the ability of the insurance agencies to assess and monitor the consolidated risk of banking institutions. The authors also argue that the federal insurance agencies should not be allowed to preempt state regulations regarding banking powers unless the new activities would result in uncompensated risk exposure of the insurance funds. 
The authors recommend that the risk of depository institutions be assessed on a consolidated basis. They argue that risks in a banking organization cannot be isolated by housing activities in nonbank subsidiaries or affiliates.

In keeping with the link of prudential supervision and regulation with the provision of federal deposit insurance, the authors recommend that only insurance agencies be responsible for prudential supervision and regulations. That includes conducting examinations and having the authority to close institutions. The authors, however, would retain the traditional feature of the regulatory structure in which depository institutions have a choice of federal chartering agency by extending federal insurance authority to the Office of the Comptroller of the Currency. Under their set of recommendations, the Federal Reserve would not have prudential supervision or regulatory authority since it would neither charter nor insure depository institutions. Moreover, Federal Reserve Discount Window emergency liquidity lending would be fully collateralized or guaranteed by the relevant federal deposit insurance agency.

In addition to risk-related insurance premiums and capital standards to compensate for, as well as to limit, the risk exposure of the insurance funds, the authors recommend measures for reducing the public uncertainty about the administration of the insurance funds, dealing with problem institutions, and changing the treatment of uninsured liability holders. They also recommend that the insurance funds be incorporated into the Treasury’s General Revenue Budget.

Other aspects of the recommendations include greater use of current (market or fair) valuation of assets and liabilities by supervisors, by depositories for risk management, and in public disclosures. They also call for focusing bank supervision more on uncovering fraud, which is argued to be a key source of bank failures, the use of information technology to enhance off-site monitoring, and the use of such monitoring to target institutions for closer examination. In line with the emphasis on safety and soundness, the authors recommend that the federal insurance agencies not be involved in supervision regarding compliance with consumer protection regulations.

One landmark legislative initiative addressing issues encompassed by the Report's recommendations is the Federal Deposit Insurance Corporation Improvement Act (FDICIA) of 1991. The act includes several provisions resembling some of the 
Report's recommendations in terms of risk-related insurance premiums as well as early intervention and closure policies. The act also clarified and formalized the condition under which emergency liquidity lending could be extended to large banking organizations - that is, explicit rules related to the treatment of institutions viewed as toobig-to-fail. The act, on the whole, is consistent with certain recommendations of the Report; though in the implementation of the act by the agencies, practices under Prompt Corrective Action still rely on book-value (not current-value) measurements, deposit premiums are only nominally risk-related, the Federal Reserve remains the effective lender of last resort, and federal agencies that are not responsible for administering deposit insurance are still involved in bank closures decisions.

The first Basel Accord formally introduced risk-related capital requirements. Consistent with the recommendations of the Report, the Accord included the extension of capital requirements to off-balance sheet activities. The Accord is vulnerable to capital arbitrage, which has been addressed in part by several supervisory initiatives, but its shortcomings still have prompted changes being proposed by Basel II. In addition, in keeping with the Report's recommendations, current valuation is used for trading books of banks, though not other assets and liabilities of banking organizations. The rise in the use of subordinated debt by larger banking organization as part of Tier 2 regulatory capital is in keeping with the general recommendation for having greater reliance on subordinated debt. Related recommendations in the Report such as the one requiring subordinated debt used for regulatory purposes to have staggered maturities were not adopted. The Gramm Leach Bliley Financial Modernization Act (GLB) of 1999 directed the Federal Reserve and the Treasury to prepare a study to consider requiring depositories to issuance subordinated debt, but such requirements were not acted on by the Congress or the supervisory agencies. On balance, the increased equity capitalization of banks, measured either on a book-value or on a market-value basis, might be the single most important development affecting the overall risk exposure of the deposit insurance system.

In addition to the changes in capital regulation, in keeping with the Report's recommendation to increase reliance on market discipline, several steps have been taken to improve public disclosure by financial institutions over the past 20 years, and 
improved disclosure is encompassed in Pillar 3 of the Basel II proposal. The agencies also have taken steps to improve disclosure by expanding the scope of regulatory reports, accelerating the release of the reports, and making the information more readily available.

Among the recommendations relating to the agencies, the agencies have enhanced off-site monitoring, both through using statistical models and utilizing information technology to access and assess data relating to supervised institutions. A major change in the process of bank supervision has been the adoption of the so-called risk-focused approach. This approach emphasizes monitoring and assessing risk management systems of depository institutions, as compared to the traditional transactions-testing approach. ${ }^{1}$ While not explicitly part of the Report's recommendations, the risk-focus approach is consistent with the recommendation to improve detection of certain types of fraud along with improvement of risk management more generally.

However, few of the Report's recommendations regarding agency structure have been adopted. Supervisory responsibility and insurance authority have not been combined fully. In fact, some ground was lost from the perspective of the Report with the creation of OTS, stripped of insurance authority. The Federal Reserve retains prudential supervision and regulation authority. Fuller financial integration under GLB does include umbrella supervision, which is consistent with the recommendation that risk be assessed on a consolidated basis. However, the reliance in GLB on the use of the holding company structure is contrary to the Report's position on the ineffectiveness of corporate separateness in isolating risk in banking. Also at odds with the recommendations of the Report is the raising of the nominal coverage of deposit insurance for retirement accounts to $\$ 250,000$.

Finally, tying prudential regulation to the deposit insurance systems highlights an important principal-agent problem in the financial system. However, some developments affecting the banking sector, while perhaps consistent with ameliorating this agency problem, are probably better understood in terms of other principle-agent relationships, externalities, or even simply firms' desire to assess better their risk-return trade-offs. Examples include the development of internal risk models by the private sector and improvements in public disclosures, both voluntary and in response to accounting and

\footnotetext{
${ }^{1}$ Both a risk focus and transactions-based assessments are part of the current examination process.
} 
regulatory guidance. Another feature of bank supervision is the stated goal of limiting systemic risk. This may have shaped the approach to supervision of large banks, the attention given to their role in the payment system, and the interactions among supervisory agencies internationally.

Following the order of presentation of the key recommendations in the Report, the rest of the paper is organized as follows: Section I-deposit insurance and lender of last resort; Section II—-market discipline; Section III—-prudential supervision; Section IV— other reform issues; and Section V-expanded banking powers. In each section, we first recap the principal recommendations in the Report, followed by a discussion and analysis of subsequent related legislative, regulatory, and supervisory developments. Section VI concludes this paper.

\section{Deposit Insurance and Lender of Last Resort}

The Report highlights the reform of deposit insurance and lender-of-last-resort policies as an especially critical area for ensuring the safety and soundness of the U.S. banking system (depository institutions system). The five areas addressed in the Report include: (1) modifications of deposit insurance pricing structure to remove mis-pricing; (2) modifications of the insurance contract; (3) changes in insolvency resolution mechanics; (4) elimination of uncertainties about the quality of the federal deposit guarantee; and (5) changes in responsibilities related to the lender-of-last-resort function.

\section{A. Modifications of deposit insurance pricing structure}

On the modifications of deposit insurance pricing structure to remove mis-pricing, first and foremost, the Report recommends using risk-related charges for deposit insurance coverage. The three options put forth by the Report are: (1) using risk-adjusted deposit insurance premiums; (2) using risk-adjusted capital standards in conjunction with a fixed charge for insurance; and (3) using a combination of risk-adjusted capital requirements and risk-adjusted deposit insurance premiums.

The Federal Deposit Insurance Corporation Improvement Act (FDICIA) of 1991 required the FDIC to establish a risk-based assessment system. To implement this requirement, the FDIC adopted a system that places institutions into risk categories based 
on two criteria, capital levels and supervisory ratings. The three capital groupings - well capitalized, adequately capitalized, and undercapitalized - are based on leverage ratios and risk-based capital ratios used for regulatory capital purposes. The three supervisory subgroupings are generally based on an institution's composite CAMELS rating CAMELS 1 or 2, CAMELS 3, and CAMELS 4 or 5. The three capital groupings and three supervisory subgroupings form a nine-cell matrix for risk-based assessments. However, the act prohibited the FDIC from charging well-managed and well-capitalized institutions deposit insurance premiums when the deposit insurance fund is at or above the Designated Reserve Ratio (DRR). In 2005, only about 6 percent of the almost 8000 commercial banks paid deposit insurance premiums.

The Federal Deposit Insurance Reform (FDI) Act of 2005 also requires that the assessment system be risk-based and allows the FDIC to define risk broadly. At the same time, the Reform Act grants the FDIC more discretion to price deposit insurance according to risk for all insured institutions by eliminating the fixed DRR of 1.25 percent. Specifically, the Designated Reserve Ratio for the deposit insurance fund is allowed to fluctuate within a range of 1.15 percent to 1.50 percent of estimated insured deposits. As such, a single value DRR no longer serves as a trigger, whether for assessment rate determination, recapitalization of the fund, or dividends.

The Reform Act also allows the FDIC to establish separate risk-based assessment systems for large and small institutions, subject to the requirement that no insured depository institution be barred from the lowest-risk category solely because of size.

Regarding risk-adjusted capital standards, the 1988 Basel Capital Accord introduced risk-based capital requirements to address a bank’s exposure to credit risk. While the credit risk categories are broad and the derivation of the risk weights was not very scientific, it was a major step towards risk-adjusted capital standards. The 1996 amendment explicitly added market risk to the regulatory capital requirements. The currently proposed Basel II refines the capital requirements against credit risk and further adds operation risk into the capital requirements.

The original Basel Capital Accord was created to achieve some degree of standardization in bank capital requirements across different countries, so that internationally active banks competing in the global lending markets face similar capital 
requirements. However, the capital rules were susceptible to capital arbitrage- that is, strategies that reduce a bank's regulatory capital requirements without a commensurate reduction in the bank's risk exposure. While supervisory initiatives were taken to deal with "loopholes” to patch Basel I, the international supervisory community has been working on the new Basel II requirements for a number of years. The Basel II framework has three pillars to promote bank safety and soundness. They are capital requirements (pillar 1), banking supervision (pillar 2), and disclosure requirements (pillar 3). Under Basel II’s capital requirements, U.S institutions would be required to maintain risk-based capital requirement using either the formulaic standardized approach or the advance internal-rating-based (IRB) approach. ${ }^{2}$ The advance IRB approach leverages the bank’s internal risk management system to set regulatory capital requirements.

So, technically, the U.S. has both risk-based deposit insurance and risk-based capital requirements. Under the current system, the risk-based deposit insurance premium is based both on the CAMELS rating and the level of book capital of an institution. However, as discussed earlier, both criteria have problems and further reforms are currently underway. Although it is premature to predict the outcomes of these reforms, it seems safe to say that the new deposit insurance pricing structure coming out of the FDI Reform Act and the new risk-adjusted capital standards due to Basel II represent improvements over the existing schemes.

Besides risk-based pricing, the Report recommends several changes related to the modification of the deposit insurance pricing structure. They include: (1) basing riskrelated deposit insurance premiums on the risk of the consolidated banking organization rather than the bank subsidiaries; (2) including the off-balance sheet risks of the banking organization in determining the risk-adjusted premium; and (3) charging insured institutions explicitly for examinations based on risk.

Currently, the deposit insurance premium is assessed for the bank only and not on a consolidated basis, despite the proliferation of nonbanking activities conducted by a number of banking organizations over the past 20 years. As will be discussed in more

\footnotetext{
${ }^{2}$ In the U.S., the so-called Basel Ia standards have been proposed. The Office of the Comptroller of the Currency, Board of Governors of the Federal Reserve System, Federal Deposit Insurance Corporation, and Office of Thrift Supervision, issued a joint advance notice of proposed rulemaking on October 20, 2005.
} 
detail below, the expansion of banking power has taken place with banking organizations being required to house many of their nonbanking activities in separate holding company affiliates. Basing the deposit insurance premium solely on the risk of the bank subsidiary assumes that the bank subsidiary can be isolated effectively from the rest of the organization. Whether this separation is plausible or feasible, both in normal times and in the event of a crisis, remains a hotly debated issue. On the assessment of the deposit insurance premium for a bank subsidiary, the base that is used in calculating the premium is the level of assessable deposits, and excludes non-deposit liabilities. However, the rate schedule, which is partly based on the CAMELS rating, reflects the risk-taking of the entire bank subsidiary, and thus should take into consideration off-balance sheet activities in the bank subsidiary.

Regarding the recommendation for risk-based charges for examinations, currently, examinations conducted by the Federal Reserve and the FDIC are funded through Federal Reserve earnings and deposit insurance premiums, respectively. As such, the two federal banking agencies do not explicitly charge for bank examinationsbased on risk or any other criterion. National banks pay an assessment to the Office of the Comptroller of the Currency (OCC) for supervision, which is the major source of funding to the OCC. The OCC fee schedule is tied to the number of hours of on-site examination, albeit not to bank risk explicitly. Similar to the OCC, the Office of Thrift Supervision (OTS) charges fees based on time spent on-site, but not risk per se. State banking commissions also charge for their examinations, although the practices and the fee schedules vary across states. The idea of using explicit charges for examinations related to bank risk can be seen as furthering the risk-based deposit insurance pricing. To that end, a perfect risk-based deposit insurance program can incorporate the risk-based examination fees into the deposit insurance premium.

\section{B. Modifications of insurance contract}

The Report recommends modifying the insurance contract to make market discipline more effective. On changing the insurance coverage, the authors point out that all depositors at all banks should be treated equally, and not granted de facto differential coverage based on bank size. However, they were ambivalent between keeping the de 
jure $\$ 100,000$ coverage and selectively rolling back the coverage to an amount significantly less than $\$ 100,000$. They did unanimously reject raising the coverage.

The deposit insurance coverage, both in terms of the level and scope, was not changed since the publication of the Report until the passage of the FDI Reform Act in 2005. Contrary to the recommendations in the Report, the recently enacted Reform Act raised the retirement account insurance coverage from $\$ 100,000$ to $\$ 250,000$. The FDI Reform Act also allows, but does not require, the FDIC to adjust the general account coverage levels to keep pace with inflation starting in 2010. It remains to be seen whether the general account coverage levels will be raised to keep pace with inflation when the FDIC has the statuary authority to do so in 2010.

The goal behind rolling back deposit insurance coverage or allowing the deposit insurance coverage to decline in real term is to increase market discipline by exposing more depositors to risk of default. Implicit in this view is that the maximum level of coverage $(\$ 100,000)$ exceeded what was sufficient to achieve the public policy goals for having federal deposit insurance. ${ }^{3}$

The argument in favor of raising the deposit insurance coverage is that the dollar coverage in real term has been declining as a result of inflation; as such, raising the nominal coverage would help restore the deposit insurance coverage in real term. Implicit in this view is that the effectiveness of deposit insurance depends on the coverage being adjusted in real terms.

Turning to the sources of coverage, the Report recommends the continuation of the reliance on the federal government to provide a basic or minimum level of insurance coverage, while encouraging development of private supplemental insurance. The collapse of the Rhode Island Share and Deposit Indemnity Corporation in 1991 ended a two-decades-long cycle of failure of state-chartered deposit insurance funds, following a

\footnotetext{
${ }^{3}$ Among the common rationales for having federal deposit insurance are discouraging runs by depositors and protecting savers with small account balances. In a public interest group framework of political decision making, another effect of a higher de jure limit on deposit insurance coverage might be to benefit smaller banking organization with limited access to money and capital markets. The force of this argument, however, likely is diluted to some degree with a large number of small commercial banks having access to Federal Home Loan Bank advances.
} 
series of failures of privately operated deposit insurance funds. Since then, we have seen little momentum for expanding the private market for supplementary deposit insurance. ${ }^{4}$

\section{Changes in insolvency resolution mechanics}

The Report recommends that the responsible insurance agency be given the authority to close economically insolvent institutions. At the time of the Report, the insurance agency had to get the chartering agency to agree to close an insolvent institution. The resulting delay could involve losses that would be borne by the insurance funds.

Currently, a failing depository institution is typically closed by its chartering authority (i.e., state banking agency for state chartered institutions, the OCC for national banks, or the OTS for federal savings institutions) when it becomes insolvent, is critically undercapitalized, is implicated in a discovery of a severe case of fraud, or is unable to meet deposit outflows. FDICIA gives the FDIC the authority to close an institution that is considered to be critically undercapitalized (having a ratio of tangible equity to total assets equal to or less than 2 percent) and that does not have an adequate plan to restore capital to the required levels. FDICIA also gives the FDIC authority to close an institution that has had a substantial dissipation of assets due to a violation of law, been operated in an unsafe or unsound manner, engaged in a willful violation of a cease and desist order, concealed records, or ceased to be insured. These conditional powers for the FDIC go part way in meeting the related recommendation in the Report. ${ }^{5}$

To protect the insurance fund and uninsured creditors, the Report recommends closing a depository institution when the market-value net worth of the institution falls below some low, but positive, number such as 1 or 2 percent of assets. In this regard, in

\footnotetext{
${ }^{4}$ There are still private insurers of deposits (credit union shares). In July of 2006, the Washington state Department of Financial Institutions invited comments on a proposal for reviving a private deposit insurance program.

${ }^{5}$ Under the Financial Institutions Reform, Recovery, and Enforcement Act (FIRREA) of 1989, if the federal banking agency to which the FDIC recommended specific enforcement action against any insured depository institution or any affiliated institution failed to take the recommended action (or acceptable alternative action) within 60 days, the FDIC could step in. Under certain circumstances, the FDIC could take immediate action. FDICIA gave the FDIC the same authority over national banks and state member banks.
} 
the early 1990s, policymakers embraced the concept of "structured early intervention and resolution” (SEIR) to mandate specific intervention by the regulatory agencies on a timely basis. After a number of attempts by the Congress, FDICIA was signed into law. While FDICIA embodied the concept of SEIR with the Prompt Corrective Action (PCA) and least-cost resolution (LCR) provisions, the triggers for regulatory intervention are based on book-value capital ratios. Relying on book-value capital ratios for prompt corrective action is viewed by the Report as inferior to using current valuations. On that score, book-value accounting measures may be less timely than current valuations when promptness of the corrective action is essential. Book values also may be subject to managerial manipulation such as by the discretion used in making loan loss provisions. On the other hand, in the absence of full market-value accounting (reporting) and given the fact that many banks are not publicly traded, book-value capital is the only readily observable measure for implementation purposes for many banking organizations.

In resolving depository institution failures, the Report also recommends imposing a pro-rata "haircut" on all uninsured liabilities to enhance market discipline, and to impose management performance requirements to ensure that management acts in the interests of the insurance agency in FDIC-assisted mergers.

The notable large bank failure since the Report was the failure of three bank subsidiaries of the Bank of New England Corporation in 1991. In the Bank of New England failure, the three failed bank subsidiaries were acquired by the partnership between Fleet/Norstar and the buyout firm, Kohlberg, Kravis Roberts \& Co. All deposits both insured and uninsured, of the three failed bank subsidiaries were protected.

In the wake of the Bank of New England failure, the enactment of FDICIA introduced specific provisions to guide the resolution of large bank failures. Under FDICIA, the FDIC is prohibited from protecting uninsured depositors or creditors at a failed bank if it would result in an increased loss to the deposit insurance fund. However, there is an exemption from this requirement for banks that regulators judge to be "too-big to-fail," and where imposing losses on their depositors or creditors "would have serious adverse effects on economic conditions or financial stability.” But this exemption requires such a determination by the Secretary of the Treasury upon the written recommendation of two-thirds of both the FDIC Board of Directors and the Board of 
Governors of the Federal Reserve System and after consultation with the president of the United States. To date, this “too-big-to-fail” exemption has not been tested.

\section{Eliminate uncertainty about quality of federal deposit guarantee}

The Report recommends that authorities publicly announce (and follow) policies to deal with depository institution insolvencies and coverage of insured deposits. While the Report was ambivalent about merging the FSLIC fund and the FDIC fund, it recommended placing the insurance funds into the U.S. Treasury’s General Fund, while retaining separate supervisory, regulatory, and premium-setting authority among the agencies.

FDICIA’s Prompt Corrective Action provisions set conditions under which early supervisory intervention would take place and the associated interventions. The leastcost resolution provisions require the FDIC to resolve bank failures using the resolution method that is the least costly to the deposit insurance fund. In addition, the FDIC publishes its failed bank resolution procedures on its website.

While the administration of the thrift and bank deposit insurance funds has been combined, the agency has maintained the BIF and SAIF separately. Very recently, the FDI Reform Act provided for the merger of the BIF and the SAIF. The merger of the two insurance funds should improve risk pooling. It also eliminates the possibility of having two potentially different deposit insurance pricing schemes for two very similar sets of institutions.

Regarding the funding of the FDIC, the agency receives no Congressional appropriations. The FDIC is funded by premiums that banks and thrift institutions pay for deposit insurance coverage and from earnings on investments. While the FDIC is an independent government agency that is self-funded, it has a line of credit from the Treasury and is widely perceived to be fully backed by the U.S. government.

\section{E. Lender of Last Resort}

The Report recommends that the deposit insurance agency(s) be able to lend directly when necessary to institutions experiencing liquidity problems; the funds could be borrowed from the Federal Reserve. It also recommends that, if the Federal Reserve 
should provide emergency liquidity to a depository institution, it should do so at the initiative and with the approval of the relevant federal deposit insurance agency and with sound collateral backing the loan. Finally, direct lending in emergency liquidity situations should be at a rate that commensurate with risk associated with the credit extended.

Contrary to recommendations of the Report, the Federal Reserve remains the lender of last resort through its Discount Window programs. In 2003, the Federal Reserve revised the programs by replacing the adjustment credit and the extended credit with ones for primary credit and the secondary credit, respectively. Primary credit is extended only to generally sound institutions at a rate that is above the target federal funds rate. Secondary credit is extended under appropriate circumstances to institutions not qualified for primary credit, at a rate above the primary discount rate.

We note that the authors of the Report do not recommend eliminating the lenderof-last-resort function, only redesigning it. The choice of having the insurance agency(s) bear the risk in providing emergency liquidity is consistent with the focus on accountability and with assessing and pricing risk correctly. In a broader context, there may be other public policy roles of the lender of last resort, such as limiting systemic risk. If limiting systemic risk is a legitimate concern for policymakers, the relevant question to ask is: will a deposit insurance agency narrowly charged with protecting the insurance fund also be effective in dealing with systemic issues?

\section{Market Discipline}

The presence of market discipline means that a firm has private sector stakeholders who are at risk of financial loss from the firm's decisions, and that the stakeholders can take actions to "discipline” the firm, i.e., influence its behavior. In the context of the Report's recommendations, the private sector stakeholders are management (including directors), shareholders, and uninsured depositors and other creditors. The Report has a general recommendation for increasing reliance on market discipline by imposing costs on stakeholders as disincentives for taking risk. ${ }^{6}$ More

${ }^{6}$ One of the recommendations is to expand stockholder liability in the event of a failure. Specifically, depository institutions should have the option of issuing shares with double liability. We are not aware of institutions having done this since the publication of the Report, though there are historical precedents for 
specific recommendations include those for greater reliance on subordinated debt. The Report also recommends expanding the use of current-value measures for internal use by depository institutions, for deposit insurance purposes, and in public disclosures. The Report argues that one of the benefits of increased market discipline is that it can supplement supervision and thus lower the expenses of the agencies. A recommendation also calls for examination reports to be shared with bank management. ${ }^{7}$

\section{A. Higher Capital requirements}

A principal set of policy measures directed at increasing reliance on market discipline from shareholders is the collection of changes to capital regulation. The regulatory agencies adopted explicit capital requirement in the early 1980s. As discussed above, the next major capital requirement initiative was the first Basel Accord, adopted in 1988 and fully effective in 1992. In the years after the implementation of the Accord, several amendments were made to the risk-based capital. The changes in part responded to expanded use of new financial instruments. One example is the supervisory directive in 1997 on capital requirements for credit derivatives. Also, among the notable changes was the application of capital requirements to the market risk of a bank's trading book. This change leveraged innovations in risk management in the private sector. Large banks and other financial institutions had developed models that encompassed their processes, procedures, and techniques, including statistical models for assessing portfolio risk. Regulators saw that these "state-of-the-art" risk-management tools provided the methodology for setting risk-based capital requirements. The internal models also provided the makings of a framework for the Basel II capital regulation to address the more general shortfalls of Basel I, at least for the largest banking organizations.

Coincidental with the increased emphasis on bank capital by the regulatory agencies has been the substantial turn around in book-value capitalization in the industry.

the recommendation. In any case, the Report's recommendation for double liability for shareholders does not appear to have received serious consideration by policymakers.

${ }^{7}$ The Report also recommends that the supervisory agencies be less hesitant in applying their authority to remove management of a depository institution promptly in situations that pose an obvious threat to the deposit insurance fund. 
The increase in book-value capital among banks has resulted in more than banking organizations' just meeting the minimum capital regulation, which requires banks to hold total capital in the amount of at least 8 percent of risk-weighted assets with at least 4 percent in Tier 1 capital. ${ }^{8}$ As discussed earlier, banks are subject to Prompt Corrective Action (PCA) regulations under FDICIA. Banks with total risk-based capital ratio of at least 10 percent and Tier 1 risk-based capital ratio of at least 6 percent are classified as "well-capitalized,” while banks with lower capital ratios are assigned lower capital categories.

Banking organizations have incentives to be classified as "well-capitalized" since it carries a number of economic benefits. These include reduced regulatory scrutiny, more operational freedom, and the ability to engage in permissible financial activities. For example, well-capitalized banks can receive expedited treatment in certain transactions including for some mergers and acquisitions that require regulatory approval. When a bank holding company applies to become a financial holding company (so that it can engage in securities underwriting and dealing, insurance, and merchant banking activities) the holding company's depository institutions must be well-capitalized at the time of the application and remain well-capitalized thereafter to avoid restrictions on engaging in financial activities.

It is not surprising, then, that nearly all of U.S. banks are not just adequately capitalized, but actually well-capitalized. Also, having many banking organization maintain capital ratios well above the thresholds for being well-capitalized, could be consistent with binding capital standards being the main driver. To the extent that raising equity capital quickly could be costly, a bank would be expected to hold a buffer of capital to limit the chances of falling below the well-capitalized cutoff.

On the other hand, as discussed below, some policy measures have been aimed at increasing the risk exposure of uninsured depositors and other bank creditors. To the extent that these stakeholders view the expected loss given bank default as having increased, a rise in bank capitalization would be consistent with increased market

\footnotetext{
${ }^{8}$ Tier 1 capital includes common stockholder equity, qualifying noncumulative perpetual stock, limited amount of cumulative perpetual preferred stock, and minority interests in the equity accounts of consolidated subsidiaries. Trust preferred securities also can account for part of Tier 1 capital.
} 
discipline from these stakeholders. This would be true for book-value capitalization to the extent that bank closure policies are based on book values. It also would be true for market-value capitalization. Indeed, along with the increase in book-value capitalization, there has been an even more notable increase in market-value capitalization. Furlong and Kwan (2006) show that the ratio of market value equity to book-value equity has increased substantially since the early 1990s for BHCs, especially for the largest BHCs.

\section{B. Increase reliance on subordinated debt}

The Report recommends increasing market discipline by raising the effective “capitalization” allowing for greater reliance on subordinated debt for regulatory purposes. The main recommendation is for greater reliance on subordinated debt to increase capital and hence increase market discipline. Related recommendations would require only using debt that is subordinated to deposits, exclude debt with covenants that might impede the ability of an insurance agency to resolve an insolvency, and require the maturity of the debt be staggered. ${ }^{9}$

Consistent with the Reports, subordinated debt is part of Tier 2 capital, which is included in total regulatory capital. While the debt used for regulatory capital purposes can have restrictive covenants and issuance is not required to be staggered, the environment is more conducive to the use of such debt in meeting capital requirements. In fact, as part of the recapitalization of the banking industry in the early 1990s, banking organization as a group did increase their reliance on subordinated debt in meeting regulatory capital requirements. The report by the Study Group on Subordinated Notes and Debentures (1999), for example, shows an increase in reliance on subordinated debt in the 1990s. More recently, policymakers have allowed trust preferred securities to meet part of Tier I capital requirements. While these do not have the features called for by the recommendations in the Report, they do involve bank holding companies issuing subordinated debt, albeit to special purpose entities.

Over the past 20 years, requiring banks to issue subordinate debt has been considered by policymakers and a number of studies have assessed the potential effectiveness of such requirements as well as presented proposals for how to structure the

\footnotetext{
${ }^{9}$ The Report would exclude debt with maturity of less than 30 days.
} 
requirements. The idea of requiring reliance on subordinated debt was considered by the FDIC in the early 1990s, but no action was taken. More recently, GLB required the Federal Reserve and U.S. Treasury to prepare a study regarding the use of subordinated debt requirements for capital regulation, but, again, no action was taken. ${ }^{10}$

Among the studies that have proposed some type of mandatory subordinated debt issuance since the publication of the Report, a common feature is a provision for regular issuance of subordinated debt by depository institutions. As in the Report's recommendations, one approach is to have staggered maturities of the debt. More restrictive requirements would have a pre-determined schedule for issuing debt. Evanoff and Wall (2000), for example, would have banks eventually be required to issue subordinated debt twice a year. Having regular issuance of subordinated debt is supported by the findings that banks might adjust the timing of issues based on their financial condition (Covitz et al. (2002)) and by the findings that the information content of subordinate debt by banking organizations is greatest at the time of new issuance by banking organizations (Evanoff and Jagatani (2004)).

\section{Too-big-to-fail}

Other measures that are consistent with the Report's recommendations are argued to have affected market discipline by increasing the risk exposure of private stakeholders, including uninsured depositors and other creditors. As noted earlier, the provisions of FDICIA regarding PCA had the potential of introducing not only corrective action but an early closure policy, and thus reducing supervisory forbearance. As structured, this provision is directed mainly at raising costs for management and shareholders of depository institutions. Another FDICIA provision requires the FDIC to use the least cost method in resolving problem banks (LCR), the principle stakeholder target being uninsured creditors. ${ }^{11}$ As discussed above, the FDICIA provisions relating to a too-bigto-fail policy — that is, the circumstances under which the agencies could extend

\footnotetext{
${ }^{10}$ Section 121 of the GLB requires large bank holding companies controlling a financial subsidiary to have at least one issue of rated debt outstanding, though not necessarily subordinated debt.

${ }^{11}$ If the administration of an earlier closure policy were expected to result in the closure of institutions with positive market value, that obviously would place more expected costs on shareholders. Indeed, to the extent that institutions have positive charter values (intangible assets) not reflected on their balance sheets,
} 
emergency liquidity assistance to a large depository institution and the procedures for the agencies to follow to determine if the circumstances apply in a particular case-may also have increased market discipline for certain depository institutions.

Views on the effectiveness of these particular provisions vary. Benston and Kaufman (1998) for example argue that PCA had an impact, even though the potential effect was diluted in part by the failure of the agencies to incorporate current-value “tripwires.” On the other hand, Rosengren and Peek (1997) concluded that PCA likely had little effect. They argue that, had PCA been in place during the banking crisis in New England, it would have had little, if any, effect. The study suggests that the PCA imposes an essentially nonbinding constraint on bank supervisors, doing little to reduce supervisory forbearance.

It does appear that implementation of LCR by the FDIC did result in larger losses to uninsured creditors, potentially increasing market discipline. In this regard, research has found that yields on bank-related subordinated debt (as well as credit default swap spreads) are sensitive to the risk of the issuing organizations. An especially pertinent study by Flannery and Sorescu (1996) concludes that interest rates on long-term bank debt tend to vary with the riskiness of an institution issuing the debt in the period 1989 to 1991, but not earlier in the 1980s. A subsequent study indicates that these results for the earlier 1980s may be related to measurement issues. Covitz et al. (2002) find that, after accounting for liquidity premiums in yields on subordinated debt, banking related subordinated debt spreads were sensitive to organization-specific risks in the mid-1980s, and that the risk sensitivity of such spreads was about the same in the pre-and postFDICIA periods.

In a more recent study, Flannery and Rangan (2006) look at the relation between market-value capitalization and asset risk among large BHCs. They concluded that the evidence supports the hypothesis that regulatory innovations in the early 1990s weakened conjectural government guarantees, thus enhancing bank counterparties’ incentives to monitor and price default risk. ${ }^{12}$

even a book-value closure rule could impose added costs on shareholders.

${ }^{12}$ Flannery and Rangan (2004) find no evidence that a BHC's market capitalization increases with its asset volatility prior to 1994, but find a strong cross-sectional relation between capitalization and asset risk after 1994. 
While the impact of certain provisions of FDICIA may be debated, as discussed in Furlong and Williams (2006), recent research consistently shows that the pricing of longer-term uninsured debt issued by banking organizations reflects firm-specific risk. The research on whether market discipline affects risk taking is more limited and less definitive. Bliss and Flannery (2001) find no evidence that market assessments of risk lead to changes in bank risk taking. However, Goyal (2003) finds that covenants in debt contracts are a source of discipline on banking organizations. In particular, the author finds that the charter value of a banking organization can affect the degree of restrictive covenants in its bond agreements. The idea is that a higher charter value provides a check on a banking organization's risk taking; the charter value typically is gauged by comparing a banking organization's market value to its book value. As referenced earlier, Flannery and Rangan (2004) also argue that, in response to market pressures, large bank holding companies with higher portfolio risk tend to have higher market equity to assets ratios after $1994 .^{13}$

Views on the implications of the too-big-to-fail related provisions of FDICIA vary and questions persist about the effect of the provisions (Stern and Feldman (2004) and Kaufman (2002)). As discussed above, under FDICIA, a bank can be declared toobig-to-fail so that uninsured liability holders would be afforded some protection, only if not doing so would have serious adverse effects on economic conditions or financial stability. On the one hand, FDICIA lays out what looks to be high hurdles for finding an institution to be too-big-to-fail, which should work to limit the exposure of the deposit insurance system. On the other hand, the act establishes an explicit policy that previously had been implicit. This elimination of ambiguity over a too-big-to-fail policy could have increased the potential too-big-to-fail subsidy for the very largest banking organizations. Recent empirical evidence, however, suggests this may not be the case. ${ }^{14}$

\footnotetext{
${ }^{13}$ A number of other studies find that market assessments of the risk of a banking organization can have other effects, though not necessarily mitigating risk taking. See Furlong and Williams (2006) for a discussion of those studies.

${ }^{14}$ For the very largest BHCs, Furlong and Kwan (2006) find a negative relationship of relative charter values to BHC assets in the period covering the later 1980s through 2003, with the magnitude of the negative effect increasing after the mid-1990s. The results are consistent with a decline in the expected
} 
D. Current (market, fair) valuation and disclosure

In principle, the pricing of risk exposure posed by depository institutions to the deposit insurance system and to private sector stakeholders requires current (market) valuations of depository institutions' assets and liabilities. The Report recommends the voluntary use of market value measurement by depository institutions for internal purposes and the mandatory use of current-value measurements for deposit insurance purposes. Regarding disclosure, the recommendations are for voluntary public disclosures by depository institutions of selected current-value measures, announcements by the (insurance) agencies of actions against depository institutions (when filed), and agencies' giving examination reports directly to depository institution management (including directors).

Consistent with the spirit of the recommendations, the use of current valuations among large banks and other financial institutions has increased over the past 20 years. In part, this reflects compliance with new accounting standards issued by the Financial Accounting Standards Board (FASB) over the past several years that affect the accounting standards and disclosures associated with financial instruments that comprise a large part of banking activities. Much of the emphasis has been on the current value of financial instruments, asset transfers, and off-balance sheet risks. ${ }^{15}$

Internal use of current-value measures is part of risk management among large depository institutions. Regarding the application of current-value measures by the banking agencies, current-value measures are part of the capital standards for market

value of the federal "guarantee" related to the protection of creditors at the banking organizations most likely to be viewed as "too-big-to-fail."

${ }^{15}$ Over the past several years, FASB has issued several standards related to current (fair) value accounting and risk exposure affecting banks, including:

FAS 107 : Disclosures about fair values of financial instruments

FAS 114 : Accounting by creditors for impairment of a loan

FAS 115 : Accounting for certain investments in debt and equity securities

FAS 119 : Disclosures about derivatives

FAS 125 : Accounting for transfers and servicing of financial assets and extinguishments of liabilities

FAS 133: Accounting for derivative instruments and hedging activities.

FAS 141: Accounting and reporting for business combinations (purchase accounting in mergers). 
risks of trading books. However, the agencies have been reluctant to adopt broader applications of current-value measures. ${ }^{16}$ Also, the FDIC generally is not required to use current-value measures for deposit insurance purposes, as recommended in the Report.

In place of the full application of current-value accounting in banking, the agencies have promoted initiatives for reporting information that can be used to assess risk exposures. An example is the joint agency guidance on asset securitization, which deals with reporting retained risk in securitization. The Study Group on Disclosure (2000) discusses the role of the banking agencies, the SEC, FASB, international banking agencies, and the private sector in the public disclosure of information on banking organizations.

One of the recommendations of that study was to convene a private sector group to identify key issues in public disclosures for banking organizations and make recommendations for voluntary enhancement to those disclosures. As a result, the Working Group on Public Disclosure was established in April 2001 by the Board of Governors of the Federal Reserve System, and it was chaired by Walter V. Shipley, retired chairman of Chase Manhattan Bank. ${ }^{17}$ The report set out a list of principles for public disclosure and identified several specific areas for improving public disclosure by financial institutions. A key principle was that disclosures should include information that is consistent with an institution's approach to risk management. It is also notable that the specific recommendations for enhancing public disclosures called for reporting information about risk exposures, rather than reporting fair-value measures per se. Nevertheless, as discussed earlier, voluntary private sector initiatives have played an important role in advancing the use of current value measures in banking. Again, one of the most notable private-sector initiatives is the development and use of internal risk models. $^{18}$

\footnotetext{
${ }^{16}$ See for example, Bies (2004).

${ }^{17}$ SR 01-6 (2001).

${ }^{18}$ The Study Group on Disclosure (2000) also recommended changes to the treatment of regulatory reports for banking organizations. In recent years, bank Call Reports and bank holding company regulatory reports have been made available electronically and the release of reports for larger bank holding companies has been accelerated.
} 
The supervisory agencies are required to make public formal supervisory actions taken against banking organizations. In 1989 and 1990, the U.S. Congress adopted legislation requiring bank regulatory agencies to make public all formal enforcement actions imposed on banks. Moreover, this enhanced disclosure was adopted during a period of great banking distress in the United States. By making the formal actions public, bank supervisors were in effect disclosing that certain institutions were believed to have a high probability of failure in the absence of substantial remedial action. In their examination of the impact of disclosing formal actions, Jordan, Peek, and Rosengren (1999) find that disclosures provide information to the market about the individual institutions.

\section{E. Use of Market information in bank supervision}

The Report argues that enhanced market discipline could reduce the cost of government supervision; specifically, enhanced oversight from market participants could supplement bank supervision by the agencies. Indeed, some policymakers have been very supportive of the idea that, with increased complexity and sophistication of large banking organizations, reliance on market signals (pricing of bank-related securities) can be an important supplement to other sources of information used in the supervisory process. ${ }^{19}$ In fact, over the past several years, financial market information has been incorporated into the bank supervision process. Burton and Seale (2005) discuss the use of market information in bank supervision by the Federal Deposit Insurance Corporation. Feldman and Schmidt (2003) document the incidence of references to financial market information in Federal Reserve supervisory reports and identify the types of market information considered. Furlong and Williams (2006) report that for the Federal Reserve System, while resources directed at the use of market information in the supervisory process remained modest, they are increasing.

At the same time, Furlong and Williams (2006) point out that there remains considerable skepticism about the ability of the market to uncover with any regularity problems among traditional banking organizations ahead of bank supervisors. That is because banking supervisors have access to confidential information and, in the case of

\footnotetext{
${ }^{19}$ See Meyer (1999) and Stern (2000).
} 
the very largest banking organizations, examiners are on-site fulltime. What is recognized, however, is that market sentiment can influence a banking organization's operations, especially its access to funding. Using the market information along with other sources of information is seen as being especially useful to bank supervisors in the face of adverse events affecting conditions in the banking industry or of a given banking organization. So, while information (related to the financial condition of banking institutions) from equity, debt, and derivatives markets is used in several stages of bank supervision and is included regularly in supervisory reports, it appears that such information is not a driver of supervisory findings regarding the financial condition of banking organizations. $^{20}$

\section{F. Examination reports and rating explicitly given to directors and senior} management

Consistent with the recommendation in the Report, follow-ups with bank management are part of the bank examination process. Senior management is provided with the examination reports and key finding are discussed with management.

\section{Prudential Supervision}

\section{A. Examination process}

The Report includes several recommendations for revising the bank examination process. The authors argue that fraud and insider abuse are major problems and the examination process should focus on uncovering fraud. The other recommendations include: directing examinations at verifying accounting and estimates of the current value of assets and liabilities; using existing data, statistical methods and computer models to monitor risk and to predict risk and identify problems; increasing the reporting of

\footnotetext{
${ }^{20}$ The first Federal Reserve System guidance for the use of financial market information by examiners was in 1994, with the issuance of SR Letter 94-47. That document directs examiners to consider equity returns as possible signals of condition for publicly traded financial institutions. The guidance was later replaced by SR Letter 95-43. More recently, the new bank holding company rating methodology, as implemented by SR 04-18, requires examiners to consider market indicators in rating the Financial component of the rating system.
} 
significant information using information technology; and charging for risk examinations of institutions based on time spent by the agencies. ${ }^{21}$

The bank supervision and examination processes have changed over the past 20 years and the agencies have taken advantage of advances in information technology. A notable change directly affecting the examination process has been the adoption of the so-called risk-focus approach. The risk-focus approach was formally announced by the Federal Reserve in 1997.

Risk-focused (risk-based) supervision has at least two key dimensions. One is that examiners can scope examinations to target activities of a banking organization that might be most vulnerable. Another is that examiners review an organization's risk management process - the level of management's expertise needed to oversee effectively an institution's business strategy; the adequacy of internal controls for monitoring a bank's activity; and the presence of contingency plans to mitigate loss in a worst-case scenario. This risk focus is supplemented with traditional transactions-testing of a sample of a banking organization's assets.

While improved risk management in banking could help protect the insurance fund, it should be noted that the adoptions of risk-focused supervision was not motivated mainly by the presence of moral hazard from mis-priced deposit insurance. Rather, the application of risk-focus supervision assumes that banks have an incentive to measure risk accurately and to manage that risk. In fact, the risk-focus approach can be seen as arising out of financial institutions' own innovations in risk management such as the development of risk models for use in determining the internal allocation of capital.

Nevertheless, the risk-focus approach, with an emphasis on controls, is consistent with the Report's recommendation to enhance the detection of fraud. In particular, it would seem to address instances of employee fraud, such as in the case of Barings. There maybe some take-back with regard to detecting fraud with fewer resources directed at transactions testing in examinations. The risk-focus approach also would seem to direct fewer resources toward verifying accounting and current-value measures. Even these potential drawbacks may be mitigated by other changes in bank supervision.

\footnotetext{
${ }^{21}$ The pricing of examinations was discussed earlier.
} 
One such change is the move to what might be called continuous supervision for larger banking organizations. Aside from having staff on-site at the very largest banking organizations and off-site monitoring more generally, supervision involves a series of targeted examinations leading up to full examinations. The targeted examinations can focus on particular areas of risk - credit risk, market risk, compliance risk, or operational risk. Fraud is considered part of operational risk.

Another dimension of bank supervision is the movement toward differential approaches to overseeing large and small banking organizations. With larger organizations seen as posing the greater risk to the financial system, more attention is given to those institutions. Whereas for smaller banks, the Federal Reserve, for example, relies almost exclusively on the reports from the primary federal banking supervisor in determining the supervisory rating for smaller shell bank holding companies. A shift of supervisory resources to focus on larger, more complex banking organizations can be seen as consistent with a goal of protecting the deposit insurance system. However, it also is consistent with a goal of directing resources at the set of institutions most likely to affect systemic risk.

As discussed earlier, a number of changes have been made by the agencies relating to current-value measures and disclosures regarding risk exposures. In addition, for larger banking organizations, the assessment of risk-management includes considerations such as the documentation and reliability of internal risk measures. Regarding accounting, a number of steps have been taken, including dropping regulatory accounting practices (RAP) and adopting generally accepted accounting principles (GAAP).

Off-site monitoring among the federal banking agencies has been expanded and improved substantially, as the agencies have taken advantage of statistical models and the advances in information technology. At the Federal Reserve, for example, off-site monitoring models are used to estimate probabilities of failures and to predict CAMELS ratings. Ongoing efforts include the development of monitoring models for holding companies, including ones that incorporate market-based variables.

\section{B. Agency Structure}


The Report includes arguments against potential changes to the structure of the agencies that would concentrate supervisory and regulatory authority. The Report rejects having a single super-agency, giving the Federal Reserve added responsibility, and having federal agencies pre-empt state regulation (in the absence of a threat to the deposit insurance system). The Report does recommend combining responsibilities for prudential supervision and regulation with those for administering deposit insurance, extending deposit insurance responsibilities to the OCC, taking the Federal Reserve out of prudential supervision, and having the other agencies (deposit insurers) focus only on prudential supervision.

Few of the Report's recommendations regarding agency structure have been adopted. The one item in the plus column for the Report is the rejection by the Congress of a single "super agency." With regard to bank supervision and regulation, the U.S. has several federal agencies that share responsibility for prudential regulation. Not only has the U.S. retained the multi-banking agency structure, it also has kept much of the silo structure regarding financial regulation more generally. This is in contrast to countries such as the U.K. that created the Financial Services Authority.

The lynchpin to agency restructuring among the Report's recommendations is tying supervisory responsibility and insurance administration. In making this recommendation, the Report's authors still would retain the traditional feature of the U.S. supervisory structure in which depository institutions have a choice of chartering agency by extending federal insurance authority to the OCC. The agencies, as deposit insurers, would not have consumer protection responsibilities and would focus only on safety and soundness.

Under the set of recommendations, the Federal Reserve would not have prudential supervision or regulatory authority since it would neither charter nor insure depository institutions. Moreover, Federal Reserve Discount Window emergency liquidity lending would be fully collateralized or guaranteed by the relevant deposit insurance agency.

The banking agency structure in the U.S. has retained the feature where banking institutions have choices among federal bank supervisors. However, no steps have been taken to combine more fully supervisory responsibility and insurance authority. In fact, some ground was lost from the perspective of the Report with the creation of the OTS, 
stripped of insurance authority. ${ }^{22}$ The FDIC still has responsibilities regarding compliance to consumer protection laws and regulations. Moreover, the Federal Reserve retains prudential supervision and regulation authority.

Indeed, in some ways the Congress expanded the responsibilities of the Federal Reserve. GLB tends to put the expansion of activities outside the banks. ${ }^{23}$ The act also gives the Federal Reserve umbrella oversight of financial holding companies. ${ }^{24}$ On the other hand, GLB puts limits on the Federal Reserve. It designates the Federal Reserve as the umbrella supervisor for financial holding companies, while the securities and insurance affiliates are subject to functional regulation by the SEC, the Commodity Futures Trading Commission, and state insurance commissions. For financial holding companies, the GLB Act directs the Federal Reserve to rely as much as possible on the functional regulators (including the primary federal banking supervisory agency) for examination and other information. As discussed above, the provisions of FDICIA related to too-big-to-fail do provide guidelines on the emergency liquidity lending, but the Federal Reserve is still a key part of the process.

\section{Other Reform Issues}

\footnotetext{
${ }^{22}$ FIRREA eliminated the FSLIC and created the OTS, under the Department of the Treasury, to assume the examination and supervision functions of the former the Federal Home Loan Bank Board (FHLBB). The act also created the Savings Association Insurance Fund (SAIF) and the Bank Insurance Fund (BIF).

${ }^{23}$ All of the new activities under GLB can be conducted in a holding company affiliate and some in a financial subsidiary of a bank. At this time, general insurance underwriting and merchant banking can be conducted only in financial holding company (FHC) affiliates. For the other activities, banks face limitations on the size of financial subsidiaries. While a number of activities, including underwriting municipal securities, can be done within the bank, most of the avenues for financial integration are pushed out to holding company affiliates or bank subsidiaries.

${ }^{24}$ Note also that even though there is umbrella supervision directed at consolidated risk of holding companies, GLB retains the concept that the bank subsidiaries can be shielded from risk transmitted from other subsidiaries. Several provisions of the act point to the primacy of protecting the banks in a FHC. For example, the act keeps in place limits on the financial transactions between a bank and the other holding company affiliates. Also, if the Federal Reserve has concerns about a bank's exposure to risk from a functionally regulated affiliate, the Federal Reserve can interact directly with the nonbank affiliate, including conducting examinations. Parallel provisions apply for financial subsidiaries of banks, including limits on financial transactions between the bank and its subsidiaries. In addition, a bank's outstanding equity investments, including retained earnings, in its financial subsidiaries are to be deducted from the bank's capital. To ensure transparency for the bank, published financial statements must present separate financial information on the bank.
} 
The Report calls for the insurance agencies to monitor deposit rates and fund flows to safeguard against risky institutions overbidding for deposits when deposit insurance is not properly priced. The supervisory agencies certainly have access to an institution's retail deposit pricing schedule and any abnormal growth in deposits likely would trigger supervisory scrutiny. While we are not aware of any systematic monitoring of retail deposit interest rates (outside of the exam process), as discussed earlier, a wide variety of market signals related to the financial condition of banking organizations is monitored regularly.

Another possible source of information, not mentioned in the Report, is the pricing of a banking organization's loans. Morgan and Ashcraft (2006), for example, advocated using loan rates to monitor bank risk taking. Their idea is intuitively appealing, but the implementation may not be trivial. Currently, the Federal Reserve collects loan rate data over a two-week period for a panel of banks each quarter in its Surveys of Bank Lending Practices. The banking agencies also have information on syndicate loans. In addition, some Federal Reserve Banks have conducted pilot projects to collect loan information for the major borrowers of large banking organizations.

\section{Expanded Powers}

The Report recommends that the main criteria for authorizing new activities should be the ability of the responsible insurance agency to monitor and to assess the total risk implications of the new activity for the consolidated entity as well as to price the risk to the consolidated entity (or to adjust capital requirements accordingly). In the views of the authors, the Glass Steagall Act's separation of commercial and investment banking, and the separation of banking and insurance, were neither necessary nor desirable for reducing conflicts of interest. Their position regarding the concentration of power is that the best way to eliminate any concerns would be to promote competition aggressively, to ease entry and exit restrictions, and to enforce existing antitrust statutes. The Report rejects the idea of housing the new activities in nonbank subsidiaries or affiliates because it would not protect the insurance agency from the risk of new activities so long as the holding company can shift risk to insured bank subsidiaries. 
Regulatory and legislative actions over the past 20 years have allowed greater affiliation of banking and other financial services. Even with the Glass-Steagall Act, in the period after 1986, bank holding companies were permitted to engage in securities underwriting and dealing on a limited basis through their so-called Section 20 subsidiaries approved by the Federal Reserve. On the insurance side, national banks exploited loopholes in the law by conducting insurance agency activities in small towns. Nonetheless, the corporate merger between Citicorp and Travelers Insurance in 1998 created the urgency to re-examine banking powers.

In 1999, the GLB Act formally repealed provisions of the Glass Steagall Act, allowing banking firms to be affiliated with securities firms and insurance companies. However, the new securities activities and the insurance activities of the banking organization must be conducted outside of the bank subsidiaries in nonbank affiliates.

To keep regulation responsive, the GLB Act gave the Federal Reserve and the Treasury the authority to define new activities that are financial in nature, or incidental to financial activities. Regarding banking and commerce, the act for the most part kept them separate (aside from allowing merchant banking activities), but left the door slightly open by letting the Federal Reserve determine when some nonfinancial activities are complementary to financial services. However, the reality of banking organizations entering new activities that are financial in nature or incidental to financial activities could be very challenging. In the years since the passage of the GLB Act, various attempts by banking companies to enter the real estate brokerage and agency activities have been effectively blocked. So far, there has not been any meaningful approval of new financial activities. ${ }^{25}$

These measures allowing greater affiliation of banking with other financial activities are consistent with the views in the Report that such affiliation should not lead to conflicts of interests that are harmful to consumers. Even the continued restrictions on mixing banking and commerce could be seen as consistent with the views in the Report, to the extent that the ban could be motivated by concerns over the ability of the supervisory agencies to assess and monitor the associated risks.

\footnotetext{
${ }^{25}$ The mixing of banking and commerce has been allowed through the Industrial Loan Company (ILC) charter. At the time of the conference, the FDIC had placed a 6-month moratorium on approving ILC applications for deposit insurance.
} 
The use of the holding company framework for expanding banking powers, however, is clearly at odds with the views expressed in the Report. A relevant question to explore is: to the extent that deposit insurance is not assessed on the risk of a consolidated enterprise, would it make sense, even in the context of a second best solution, to at least try to isolate the banking subsidiary from the rest of the organization? As indicated earlier, placing certain new activities of a financial holding company in nonbank subsidiaries per the GLB Act was an attempt to protect insured bank subsidiaries. Going back to our earlier discussion of the deposit insurance reform proposal regarding whether the enterprise risk or just the bank risk should be used for the pricing of deposit insurance, perhaps a larger question relevant to this debate is the longstanding one over corporate separateness. That is, can a bank subsidiary be effectively insulated from the rest of the organization? What are the social benefits and costs of the universal banking model versus the holding company model?

Regarding the supervision of banking firms that engage in nonbank financial activities, the GLB Act designates the Federal Reserve as the umbrella supervisor of financial holding companies, and the functional regulators as the supervisors of the nonbank affiliates. The rational for having an umbrella supervisor is that large financial institutions tend to manage their risk on a consolidated basis and operate along business lines that cut across legal entities. At the same time, several provisions of the GLB Act are intended to insulate a banking organization's depository subsidiaries from the risk of other affiliates. For example, the dealings between a bank and other financial affiliates have to be made at arms-length and on market terms. They also are subject to quantitative limits and collateral requirements. Other regulations are in place to limit the ability of a holding company to use fees paid by its subsidiary banks to transfer funds to other affiliates.

\section{Conclusions}

The Perspectives on Safe and Sound Banking, written 20 years ago when the nation's banking and thrift sectors were in serious distress, took a broad and deep look at the issues contributing to the banking problems. The Report made a number of recommendations to improve the efficiency, performance, and safety of the banking 
system by changing the structure of the deposit insurance system and the bank regulatory and supervisory process. The recommendations are based on economic principles, including the theory underlying options pricing models and agency theory in finance.

Certainly, today we have a much healthier banking and thrift sectors, with institutions registering record profits. Compared to the 1980s and early 1990s, there seems to be little question that the safety and soundness of the banking system has improved substantially—at least for now. Looking back, one can point to several major developments that have shaped the U.S. banking system during the last two decades. Among these are the recapitalization of the banking industry, financial market innovations and increased sophistication of risk management, and greater overall efficiency.

These developments are consistent with and to some extent connected to public policy measures that are in keeping with the set of recommendations laid out in the Report. We see the primary thesis of the Report as being that a safe and sound banking system requires that risk-taking incentives among depository institutions are appropriately aligned and the scope of the federal safety net is limited. Accordingly, the Report highlights the moral hazard problem of fixed-premium deposit insurance as a major source of instability. The other general areas of focus in the Report are the promotion of market discipline in banking and reform of prudential supervision and regulation of depository institutions. The core recommendations in the Report directed at these general areas of concern include adopting risk-based deposit premiums, instituting risk-based capital requirements, implementing early intervention and closure policies, making wider use of current (market) valuations of assets and liabilities, increasing reliance on market discipline from uninsured creditors, and aligning agencies' accountability regarding prudential regulation and protection of the deposit insurance funds.

In this article, we have examined how the recommendations in the Report map to the myriad legislative initiatives and regulatory and supervisory developments over the past 20 years. For one of the core set of recommendations, those related to the administration of deposit insurance, the authority and framework for risk-based deposit 
premiums are in place. However, as a practical matter, differential pricing of deposit insurance likely has had a minimal effect on incentives for risk-taking.

We would argue that the much more ground has been gained in protecting the deposit insurance system through the increase in bank capitalization, both in terms of book-value and market-value of equity. The increase in equity capitalization has coincided with greater regulatory and supervisory emphasis on higher capitalization as well as tying capitalization to risk. Still, it is uncertain as to what extent the increased capitalization in banking can be attributed directly to capital regulation or to market forces. However, having market forces play an important role in the recapitalization of banks is consistent with a goal of increasing reliance on market discipline.

Indeed, it appears that the concept of promoting market discipline in banking has been incorporated broadly in public policy. This is reflected in a range of initiatives from the provisions of FDICIA to pillar 3 of Basel II. The agencies also have been laying down the infrastructure for greater reliance on market information by incorporating market data in banking supervision and pushing the frontiers in public disclosure. Among banking organizations, reliance on subordinated debt has increased since the early 1990s. Moreover, the empirical evidence shows that uninsured depositors and other creditors are sensitive to the overall risk of individual banking organizations.

The goal of enhancing market discipline in large part is to curtail the de facto scope of deposit insurance. The provisions of GLB relating to the extension of emergency liquidity to larger institutions also likely reinforced the market's views that some banking organization would not be eligible for such credit. The uncertainty is over whether the more explicit policy on too-big-to-fail reduces the ambiguity regarding the treatment of the very largest banking organizations. On that score, some empirical evidence suggests that, overall, the conjectural government guarantees associated with the federal safety net may have been reduced.

Another key development that is in keeping with the Report is the improvement in risk management. Risk management is mainly about identifying, measuring, and pricing risk correctly. The issue of moral hazard from deposit insurance aside, bank shareholders and uninsured creditors have an interest in banks' measuring risk accurately. Advances in financial modeling and in information technology enabled the development of more 
sophisticated risk management tools, making effective enterprise wide risk management a realizable goal for large financial organizations. Interestingly, leveraging these developments in the private sector, banking regulators also shifted their supervisory approach towards risk-focused banking supervision, reinforcing the importance of sound risk management in banking.

In connection with promoting market forces and measuring risk, initiatives have led to greater use of current (market) valuations, both for internal use by large depository institutions and in capital regulations. However, full market-value accounting has not had broad support in the private sector or by policymakers. Rather, in banking the emphasis has been on initiatives for reporting information that can be used to assess risk exposures and, thus, indirectly get at current valuations.

Among the recommendations in the Report that were not adopted are those stipulating certain features of subordinated debt used for regulatory purposes. Regarding other recommendations in the Report, the one for pricing deposit insurance based on the consolidated risk of the banking enterprise does not seem to have received much attention. Furthermore, contrary to the Report's recommendation, the deposit insurance coverage for retirement account has been raised substantially, and the coverage for other deposits could begin to rise with the rate of inflation after 2010.

The recommendations for supervisory reforms have gotten only limited traction. While several developments are consistent with the Report's recommendations, such as using off-site monitoring and early warning system, the supervisory agencies have not been restructured along the lines suggested by the Report. Prudential regulation and deposit insurance administration have not been fully linked. While the Federal Reserve revised the Discount Window programs by raising the discount rate above the market rate, it remains the lenders of last resort and continues to supervise state member banks and bank holding companies. Indeed, as the umbrella supervisor of financial holding companies, the Federal Reserve's supervisory role has expanded in some dimensions.

Overall, public policy and private sector initiatives appear to have contributed to safer and sounder banking and thrift sectors over the past 20 years. Consistent with what we see as the main theme of the Report, a likely contributing factor is the more appropriate alignment of incentive for risk-taking among larger depository institutions. 
Developments affecting risk-taking by depository institutions likely include higher capitalizations, greater risk exposure of private sector stakeholders more generally, improvements in risk management, and supervision and regulation that is focused on overall risk. 


\section{References}

Benston, George J., and George G. Kaufman, 1998, .Deposit insurance reform in the FDIC Improvement Act: The experience to Date. Economic Perspectives, Federal Reserve Bank of Chicago, Second Quarter, pp. 2.20.

Benston, George J., Robert A. Eisenbeis, Paul M. Horvitz, Edward J. Kane, and George G. Kaufman, 1986, Perspectives on Safe and Sound Banking, Cambridge, MA: MIT Press.

Bies, Susan Schmidt. 2004. Remarks to the International Association of Credit Portfolio Managers General Meeting, November 18.

Bliss, Robert, and Mark Flannery. 2002. "Market Discipline in Governance of U.S. Bank Holding Companies: Monitoring vs. Influencing.” European Finance Review. 6, pp. 361-395.

Burton, Steven, and Gary Seale, 2005. “A Survey of Current and Potential Uses of Market Data by the FDIC,” Banking Review, Federal Deposit Insurance Corporation, Vol 17, No. 1. pp. 1-17.

Covitz, D. M., Hancock, D., Kwast, M. L. 2002. “Market Discipline in Banking Reconsidered: The Roles of Deposit Insurance Reform, Funding Manager Decisions and Bond Market Liquidity.” Board of Governors of the Federal Reserve System, Finance and Economics Discussion Series 2002B46.

Evanoff, Douglas, and Julapa Jagtiani. 2004. "Use of Supervisory and Monitoring Process and to Enhance Market Discipline.” Manuscript.

Evanoff, Douglas, and Larry Wall. 2000. “Subordinated Debt as Regulatory Capital: A Proposal for Regulatory Reform. Economic Perspectives. Federal Reserve Bank of Chicago, pp. 41-53.

Feldman, Ronald and Jason Schmidt, 2003. "Supervisory Use of Market Data in the Federal Reserve System.” Federal Reserve Bank of Minneapolis, Manuscript.

Flannery, Mark J. and Kasturi P. Rangan. 2004, "What Caused the Bank Capital Build-up of the 1990s?” FDIC Center for Financial Research Working Paper No. 2004-03 (August).

Flannery, Mark, and S. M. Sorescu. 1996. "Evidence of Bank Market Discipline in Subordinated Debenture Yields: 1983-1991.” The Journal of Finance vol. 51 pp. 13471377. 
Furlong, Frederick T. and Simon Kwan. 2006. "Sources of Bank Charter Values,” Federal Reserve Bank of San Francisco. Manuscript.

Furlong, Frederick T. and Robard Williams. 2006. "Financial Market Signals and Banking Supervision: Are Current Practices Consistent with Research Findings?” Economic Review, Federal Reserve Bank of San Francisco. pp. 17-30.

Goyal, Vidhan. 2003. "Market Discipline and bank risk: Evidence from subordinated debt contracts.” Hkust Business School, Hong Kong University of Science and Technology Working Paper Series.

Jordan, J. S., J. Peek and E. S. Rosengren, 1999, “The Impact of Greater Bank Disclosure Amidst a Banking Crisis,” Working Paper, Federal Reserve Bank of Boston.

Kaufman, G. G., 2002, “Too big to fail in U.S. banking: Quo vadis?” Quarterly Review of Economics and Finance, summer, pp. 423-436.

Rosengren Eric S. and Joe Peek. 1997 "Will Legislated Early Intervention Prevent the Next Banking Crisis?” Southern Economic Journal. vol. 64, no. 1 (July 1997) pp. 268280.

Morgan, Donald P., and Adam B. Ashcraft. 2006. "Using Loan Rates to Measure and Regulate Bank Risk: Findings and an Immodest Proposal.” Journal of Financial Services Research, vol. 24 No. 2-3, pp. 181-200 (forthcoming).

Stern, G. H. and R. J. Feldman, 2004, Too big to fail: The hazards of bank bailouts, Brookings Institution Press, Washington D.C.

Stiroh, K. J., and Adrienne Rumble 2005, “The Darkside of Diversification: The Case of U.S. Financial Holding Companies.” Journal of Banking and Finance (May).

Study Group on Disclosure. 2000. “Improving Public Disclosure in Banking.” Staff Study 173. Board of Governors of the Federal Reserve System. March.

Study Group on Subordinated Notes and Debentures. 1999. "Using Subordinated Debt as an Instrument of Market Discipline” Staff Study 172. Board of Governors of the Federal Reserve System. December.

SR 01-6. 2001. Enhancement to Public Disclosure. Division of Banking Supervision, Board of Governors of the Federal Reserve System. 